\title{
Q.
QNEEN'S
UNIVERSITY
BELFAST
}

\section{Amateurs versus Professionals: Explaining the Political (in)Experience of Canadian Members of Parliament}

Pow, J. T. (2018). Amateurs versus Professionals: Explaining the Political (in)Experience of Canadian Members of Parliament. Parliamentary Affairs, 71(3), 633-655. https://doi.org/10.1093/pa/gsx082

Published in:

Parliamentary Affairs

Document Version:

Publisher's PDF, also known as Version of record

Queen's University Belfast - Research Portal:

Link to publication record in Queen's University Belfast Research Portal

Publisher rights

(C) The Author(s) 2018. Published by Oxford University Press on behalf of the Hansard Society. This work is made available online in accordance with the publisher's policies. Please refer to any applicable terms of use of the publisher.

\section{General rights}

Copyright for the publications made accessible via the Queen's University Belfast Research Portal is retained by the author(s) and / or other copyright owners and it is a condition of accessing these publications that users recognise and abide by the legal requirements associated with these rights.

Take down policy

The Research Portal is Queen's institutional repository that provides access to Queen's research output. Every effort has been made to ensure that content in the Research Portal does not infringe any person's rights, or applicable UK laws. If you discover content in the Research Portal that you believe breaches copyright or violates any law, please contact openaccess@qub.ac.uk. 


\section{AMATEURS VERSUS PROFESSIONALS: EXPLAINING THE POLITICAL (IN)EXPERIENCE OF CANADIAN MEMBERS OF PARLIAMENT}

In contrast to many democracies that lament the rise of professional politicians, 'amateur' politicians have typically dominated federal politics in Canada. What explains this general lack of political experience among Canadian MPs? This study tests three hypotheses on career development by analysing individual-level data on over 1,000 MPs elected to the Canadian Parliament between 1993 and 2015. Conceptualising politics as a career path in its own right, it finds that at the key stages of establishing, maintaining, and disengaging from a federal political career, there are specific challenges facing candidates and MPs in the Canadian context that are not significantly ameliorated by the possession of prior political experience. This leaves little incentive for individuals to work in the field of politics itself before standing for federal office.

\section{Keywords:}

Political careers; political experience; professional politicians; representation; career development theory 
From dentistry to plumbing, midwifery to air traffic control, there are plenty of career paths for which prior specialist training is essential. Being a politician in a national legislature is not one of them, but - for better or worse - some people do indeed train to be politicians. In Britain, the trend towards the professionalisation of politics has been widely viewed as problematic. For King (1981: 278), the rise of the 'career politician' means that 'increasingly ... politicians without a great deal of first-hand experience of the world outside politics are running the country.' As a crude proxy for a general life experience, the narrowing of occupational experience may restrict the quality of representation that politicians can collectively offer the electorate (Cairney, 2007; Criddle, 2010; Cowley, 2012). In Canada, however, the literature has highlighted the relative amateurism of elected members of parliament (MPs) (Franks, 1987; Docherty, 1997). In this context, it is the lack of political professionalisation among MPs that may pose the greater threat to the effective functioning of democracy.

There are two principal forms of political amateurism in Canadian federal politics: amateurism as limited experience, and amateurism as limited tenure (Docherty, 1997). Political amateurism, antonymous to political professionalism, can be understood both in terms of an MP's career before getting elected and after entering parliament. Whereas Docherty (1997) primarily frames his analysis around the latter phenomenon, the present research question is concerned with the former. Why are there so few MPs in Canada for whom politics $i s$ their career before reaching Ottawa? In this article professionalism is distinguished from amateurism purely on the basis of pre-parliamentary experience: professional politicians are individuals who have already worked in the field of politics 
before getting elected to the federal level; amateurs enter the House of Commons with no such experience. ${ }^{1}$

Drawing on career development theory, this article adapts Super's (1957) seminal classification of career development according to progressive stages: establishment, maintenance and disengagement. If political experience were an asset to career development in national politics, we would expect professional politicians to enjoy clear advantages over those without prior political experience. Professional politicians should be able to establish themselves securely on the political career ladder, to acquire and maintain stability in their profession, and to disengage from their role having reached the peak of their career. We do not expect to observe this pattern in the Canadian context. Accordingly, we develop three respective hypotheses on establishing, maintaining and disengaging from a career in the House of Commons to account for the relative scarcity of MPs with occupational experience in politics itself, and thus the relative dominance of political amateurs.

To provide a systematic account of political career development in Canada, this paper analyses individual-level data on MPs elected between 1993 and 2015. The overall finding is consistent with existing literature in that professional politicians by no means dominate the Canadian House of Commons. However, the fact that a sizeable minority of MPs serving between 1993 and 2015 have at least some prior political experience - even if it does not amount to their primary career - challenges the extent of amateurism that is traditionally assumed. The relative scarcity of those with professional experience

\footnotetext{
${ }^{1}$ This reflects the approach of other studies measuring political professionalism on the basis of MPs' preparliamentary occupations, not in terms of their tenure once elected (see Criddle, 2010: 328). It should be stressed from the outset that the word 'amateur' is not used pejoratively, but simply describes an MP without professional political experience prior to election to the House of Commons, providing a direct contrast with a 'professional' politician.
} 
primarily in politics itself can be understood by the challenges facing all Canadian MPs in establishing, maintaining, and disengaging from their federal political careers. Prior political experience is not associated with a clear advantage at any of these stages of career development. 


\section{Political experience and political career development}

A career path in any occupational field may be highly planned or completely random; most likely, it involves a mixture of both coordination and making the most of opportunities that emerge along the way. Mitchell et al. (1999) advance a theory of 'planned happenstance' whereby careers arise out of both prior preparation and unexpected events. A career in politics may be no exception, but key features of the Canadian political system make it particularly difficult to plan such a career at the federal level. By conceptualising any career as a progression through various stages establishment, maintenance, and disengagement - Super's (1957) taxonomy provides a logical framework for the general study of career development. By applying it to the field of politics, this approach generates testable hypotheses to account for the dominance of political amateurs among Canadian MPs. ${ }^{2}$

In the first instance, the lack of an obvious career ladder below parliament (in the selection process) and within parliament (in cabinet promotions) undermines the prospect of an ambitious individual from initially becoming established in federal politics. Ambition is surely a driving force behind any political career: 'Politics thrive on the hope of preferment and the drive for office' (Schlesinger, 1966: 1). In the Canadian case, however, there may be little incentive for an individual to channel his or her political ambition into the development of pre-parliamentary political experience.

At the selection stage, the nature of party organisation weakens the connection between the lower and higher rungs of career progression. The separation of federal and

\footnotetext{
${ }^{2}$ Super's (1957) general taxonomy of career stages is selected as a framework of analysis due to its broad applicability to political career paths, as well as its prominence in career development literature over time (see Arthur, 2008). Similar taxonomies can be found, for example, in Aryee et al. (1994) and Hess and Jepsen (2009). To the best of the author's knowledge, this taxonomy has not previously been directly applied to the analysis of political careers.
} 
provincial party structures, and the typical absence of party politics at the municipal level 'inhibit the development of partisan career ladders' that are possible in other systems, even federal ones (Carty and Cross, 2010: 198). In the United States, Schlesinger (1966) observes that candidates can safely compete for a higher level of political office with minimal risk. Incumbency gives them an edge in their pursuit, boosting fundraising leverage, and candidates rarely face any restrictions on running for a higher level of office while still occupying another (see Rohde, 1979). This allows a hierarchical path to emerge. In Canada, however, progressive ambition incurs greater risk. Spending limits on local campaigns decrease the benefits of incumbency (Atkinson and Docherty, 1992). Meanwhile, provincial rules that prohibit an individual from seeking federal office during their provincial term significantly increase the risk attached to a would-be federal candidate resigning from their current post (Docherty, 2011). As a consequence, rather than providing a stepping-stone to federal political office, a political career in provincial politics is almost always seen as an alternative (Barrie and Gibbins, 1989). A political career in Ottawa is simply not the only 'game in town' for the politically ambitious (Matthews, 1984).

The statutory constraints posed by federalism could be ameliorated, however, if political parties were themselves more integrated across different levels of government. Instead, their degree of decentralisation remains comparatively high (Rahat, 2007). This further impedes upward mobility. It is telling, for example, that even where MPs hold prior electoral experience at another level, their federal nomination is dismissed as 'accidental' rather than as strategic career progression (Samara Canada, 2010). Katz (2001) argues that the selection process of federal candidates in Canada does not 
necessarily rely on party political networks, but simply on general personal networks. Successful candidates 'will enrol large numbers of personal supporters immediately before the candidate selection process for the sole purpose of having themselves chosen as candidates' (Katz, 2001: 291). This leaves both local party activists and the central party apparatus with little control over the selection of candidates based on their prior political experience, thus undermining the emergence of a clearly identifiable pathway connecting different levels of political office.

A professional politician, however, does not need to rise from municipal office to federal office in order to be considered such. Alternatively, the most ambitious and intentional of political professionals may rationally seek accelerated advancement from, for example, working as a political researcher for a parliamentarian before standing for federal office themselves. Serving this kind of apprenticeship would require a degree of geographical mobility that, while necessary and desirable in many prestigious career paths, is less straightforward in the political field. In Canadian politics there is a normative lack of tolerance towards 'parachuting' politically experienced candidates into certain seats (Carty and Eagles, 2005). In contrast to Britain, Docherty (2011: 186) suggests that 'it is far less acceptable for ambitious candidates to seek out winnable districts.' This leaves federal parties with relatively little control in helping to recruit candidates with extensive knowledge of the political game (Docherty, 2011). Instead, as we have seen, candidate selection is 'largely controlled locally by the members of party constituency associations' (Erickson, 1997: 33). Since these associations tend to place few formal requirements on prospective candidates, and since being locally well connected can be much more valuable than the possession of political experience, 
external recruitment is unlikely. It is only in ridings (constituencies) where a party is historically weak that it is forced to broaden the recruitment pool (Carty and Eagles, 2005). Yet if a party is locally weak, its nomination is unlikely to appeal to political professionals who are seriously pursuing a federal career.

Recent work, however, challenges some of these assumptions. Koop's (2011) analysis of the Liberal Party suggests greater integration between different levels of party organisation than previously understood, while its so-called 'open' nominations for the 2015 federal election reveal the potential for the centre to overturn local decisions. Nonetheless, the very fact that the central party was robustly criticised by local party leaders for its 'intrusion' ahead of the 2015 federal election confirms the normative undesirability of candidates being parachuted into unfamiliar ridings (Silcoff, 2014; see also Pruysers and Cross, 2016).

Within parliament, the apparent lack of meritocracy in promotions is well documented. There is, indeed, a wide range of literature on ministerial appointments (see Savoie, 1999; Kerby, 2009). White (2005) claims that cabinet promotions are a function of the 'representative imperative', viz an MP's socio-geographical characteristics are more important determinants of promotion than any political experience or qualifications potentially suited to a given portfolio. Prime ministerial appointments conventionally give strong consideration to regional and linguistic representation (Docherty, 1997). ${ }^{3}$ Kam (2006: 574) disputes the importance of these regional conventions in cabinet promotions but, crucially, still finds merit to be 'disregarded at promotion time.' The

\footnotetext{
${ }^{3}$ Between 1985 and 2015, cabinet ministers were allocated additional responsibilities as 'regional ministers' (see Bakvis, 1989). This gave them a strategic focus on economic development at the regional level across six geographical areas. Justin Trudeau abolished the concept when he became prime minister in 2015 , but commentators noted the apparent persistence of regional balance as at least one factor behind Trudeau's ministerial appointments (Hepburn, 2015).
} 
limited scope for advancement based on an individual's prior preparation, thus, facilitates the promotion of political amateurs and provokes frustration among those with direct political experience (Franks, 1987).

Compounding the lack of predictability in establishing one's political career, high levels of involuntary turnover undermine an MP's ability to maintain it. This phenomenon is the consequence of routinely competitive electoral cycles that allow for few safe seats, in contrast to the British system, for example (Franks, 1987; Docherty, 2011). In an empirical study of elections between 1867 and 1968, Casstevens and Denham (1970) found that the number of 'survivors' in the Canadian House of Commons decreased exponentially. Subsequent research has continued to detect significant electoral volatility (Bittner and Koop, 2013). This results in a high level of involuntary turnover among incumbent MPs, compared to other systems with a single-member plurality electoral system. Moreover, many incumbent MPs may be incentivised to voluntarily step aside when they anticipate a high likelihood of defeat (Kerby and Blidook, 2008). It would be understandable for elected politicians to jump before they are pushed in any national system, particularly if they represent the governing party and a change of government is expected. The key point about the Canadian context is the sheer magnitude of potential seat changes in the event of a change in government.

Finally, those who are fortunate enough to be in a position to choose when to disengage from their political careers tend to do so prematurely. High involuntary turnover is exacerbated by the tendency of MPs to perceive their involvement in federal politics to be a 'short-term interlude in a career outside of politics' (Franks, 1987: 72). This interstitial conception of political service generates high levels of voluntary turnover 
(Atkinson and Docherty, 1992; Kerby and Blidook, 2011). Such high levels of turnover are relatively unique to Canada, and cannot simply be attributed to electoral volatility (Matland and Studlar, 2004). It is an anomalous pattern that leads Kerby and Blidook (2008: 3) to quip, 'students of Canadian politics are concerned with how to keep the rascals in, not how to kick them out!' Once they make it to Ottawa, MPs may not understand, or even like, the job (Loat, 2011; Franks, 1987). Docherty (1997) builds on this conjecture to provide a rational choice explanation of voluntary turnover. New MPs enter parliament with a set of expectations. These personal hopes may change over time, shaped by institutional dynamics. After certain windows of opportunity for promotion appear to close, overlooked members calculate that their utility is not best maximised in parliament itself. Kerby and Blidook (2011) find that those who enter parliament expecting to make an individual policy impact are twice as likely to leave because they soon become dissatisfied. MPs with an established career prior to entering federal politics have a sense of occupational security that is largely absent from public life, and so often return to this career (Kerby and Blidook, 2008). Professional politicians may be less likely to disengage from parliament prematurely as they enter their federal career with direct political experience, and so perhaps have more realistic expectations as to what can be achieved. These individuals nonetheless face two challenges: they still face a high risk of involuntary exit, and those who are able to choose the timing of their exit may come to share the dominant view that their service in parliament is interstitial to their broader career, even if their primary career is in politics itself. 
In sum, the challenge of becoming established on a clear political career path, the challenge of maintaining a federal career, and the tendency to disengage prematurely from a federal political career, cumulatively lead us to expect that there are few career development incentives that foster the emergence of a large number of professional politicians. As such, this section has generated three hypotheses that are summarised in Table 1. 


\section{Data and method}

This study presents data on 836 MPs serving between 1993 and $2015 .{ }^{4}$ Data were also collected on over 300 MPs newly elected in the 2011 and 2015 federal elections, along with the unsuccessful candidates finishing second in their ridings. ${ }^{5}$ Relevant information was obtained from online records published by the Library of Parliament (2016), and corroborated where possible against biographical information provided on individual MPs' websites, social media profiles, and by local media reports.

The key explanatory variable of interest is a binary measure of whether or not an MP can be considered a professional politician. Recognising the different types of professional experience that exist in the field of politics, three distinct categories of professional politician are created. The first is the purest and most obvious, entailing any MP whose primary occupation prior to entering parliament was in politics itself. This group includes staffers, political researchers and assistants to politicians. Allowing for less linear career paths, a second group encompasses MPs whose primary occupation before their election was in a field other than politics, but who at some stage worked in politics in a secondary capacity. These include, for example, teachers and entrepreneurs who worked primarily in education and business respectively, but who then went on to provide professional political assistance to a party or parliamentarian after withdrawing from their primary career. The final group includes any MP with prior electoral

\footnotetext{
${ }^{4}$ The sample encompasses all but two MPs who served at some point between the $35^{\text {th }}$ and $41^{\text {st }}$ iterations of the Canadian Parliament. Two members did not provide vital demographic details (despite follow-up requests), and so are excluded from the analysis.

${ }^{5} 109$ MPs established their parliamentary careers in 2011. In these ridings, complete data were recorded for 109 winners (98\%) and 108 runners-up (97\%). In the 2015 federal election, 214 new MPs were elected. In these ridings, complete data were recorded for 211 winners (95\%) and 172 runners-up (81\%).
} 
experience at the municipal, provincial, or federal levels. ${ }^{6}$ Each of these three categories is mutually exclusive; the small number of MPs who possess both prior electoral and primary or secondary experience are analysed in discrete categories of their own. ${ }^{7}$

The three hypotheses outlining the challenges facing professional politicians in the Canadian Parliament are each tested with either logistic or linear regressions, as appropriate. Any advantage in the establishment of a parliamentary career is captured by two dependent variables. First, a dichotomous variable is created for winners and runners-up in the ridings that elected a new MP in the 2011 and 2015 federal elections respectively. The goal is to compare the candidates who managed to establish their federal careers against those they defeated. Controlling for membership of the winning party (nationally) and whether or not the seat changed party hands, we investigate whether or not political experience predicts finishing first over finishing second. Here we also control for whether or not a candidate is originally from the riding being contested, given voters' possible scepticism of candidates who get 'parachuted' into unfamiliar ridings. ${ }^{8}$

Second, an MP's career establishment within parliament is captured according to whether or not they were promoted to cabinet. By restricting our analysis to former MPs serving at a time when their party was in government, we control for whether or not an MP was promoted for geographical considerations. This involves accounting for the

\footnotetext{
${ }^{6}$ Prior experience at the federal level is only counted where a returning MP has had a break in tenure, i.e. he or she has exited parliament voluntarily or involuntarily and has subsequently re-entered at a later stage. 725 out of 836 possess both electoral and primary political experience; a further four possess both electoral and secondary political experience. By definition, no MP can logically possess both primary and secondary professional experience in politics.

${ }^{8}$ If an MP is elected to a riding that is within his or her city of origin, or an adjacent riding, he or she is coded ' 1 '. This reflects the fact that it is not always determinable whether or not an MP grew up in an urban riding. For example, Mark Adler, originally from Toronto, represented the city's York Centre riding, but it is not possible with the available data to establish whether or not he is necessarily from that riding originally.
} 
proportion of all MPs represented by the province in which the MP's riding is located; MPs from provinces with sizeable representation may have a lower chance of promotion compared to those from provinces that have lower parliamentary representation. ${ }^{9}$ This variable is only useful, however, in conjunction with another: the strength of the governing party in an MP's province or territory. This is measured as the percentage of seats held by an MP's party in his or her province or territory at the earliest moment that he or she becomes eligible for promotion to cabinet. ${ }^{10}$

To assess whether or not an MP with prior professional experience in politics has any advantage at the stages of career maintenance and withdrawal, we test the remaining two hypotheses respectively with involuntary exit and tenure as two additional dependent variables. In all models, we control for an MP's age at entry; the younger an MP enters the House of Commons, the less likely he or she is to have had much occupational experience, let alone political experience, and arguably the more likely he or she is to remain in parliament and to eventually be promoted.

\footnotetext{
${ }^{9}$ The percentage of seats for each province or territory is held constant at the most recent distribution.

${ }^{10}$ This moment is essentially when an MP first finds himself or herself as a member of a governing party. The Hon. Rob Merrifield, for example, was first elected in 2000 for Yellowhead in Alberta. It was not until 2006, however, that his party, the Conservative Party, entered government. It was at this moment in 2006, therefore, that Merrifield was first eligible for promotion to cabinet.
} 


\section{Results}

Only 8\% of MPs serving between 1993 and 2015 had a primary occupational background in politics itself prior to their election. A similar proportion (9\%) entered parliament with some professional political experience, but with a principal career outside of politics. Perhaps more surprising is the much higher frequency of MPs with prior electoral experience in politics: nearly one in three previously held an elected office. In total, this means that $45 \%$ of MPs serving during this period can be described as professional politicians to some degree. ${ }^{11}$ On the one hand, this relatively high figure challenges the conventional wisdom that the Canadian House of Commons is overwhelmingly dominated by political amateurs. On the other hand, however, it does confirm that professional politicians are in the minority overall and, more importantly, that they come in different forms.

\subsection{The Challenge of Establishing a Political Career}

An ideal test of the first hypothesis would estimate the effect of political experience on the performance of all candidates across a series of elections. If it helped candidates to get elected, all else equal, professional politicians would be more likely to win a seat compared to those without prior experience. If it made no difference (as hypothesised), political experience would have no significant effect on the probability of success. Due to the limited biographical information available for unsuccessful parliamentary candidates, samples are taken from candidates competing in the two most recent federal elections. Specifically, these include the newly elected MPs in the 2011 and 2015 elections and

\footnotetext{
${ }^{11}$ Descriptive frequency data for professional experience are presented in Appendix A.
} 
their nearest opponents. ${ }^{12}$ Does the possession of political experience help explain why some candidates were able to establish their parliamentary careers in these elections while their opponents finished as runners-up?

\section{< Table 2 here >}

Table 2 offers little evidence that individuals with a professional background in politics enjoy any automatic advantage in reaching federal office. Among MPs newly elected in 2011 (and their closest challengers), the possession of prior political experience was not a significant predictor of finishing first over finishing second. Indeed, candidates with primary political experience were significantly less likely to win. In contrast, by far the strongest predictor of getting elected was a candidate's party label. The odds of successfully establishing a parliamentary career in the 2011 federal election were approximately five times higher simply by being a candidate for the party that won nationally; in this case, the Conservative Party. Controlling for a seat changing hands (in any direction), being on the winning side appears to matter much more than a candidate's personal attributes. In the 2015 election the general pattern was broadly, but not entirely, similar. In ridings that elected a new MP, being a candidate for the incoming party of government, the Liberal Party, was associated with significantly higher odds of winning the seat over finishing in second place.

While most forms of political experience were statistically unrelated to electoral success in 2015, Table 2 shows that two types of professional profile were indeed significant. In this election, candidates with prior electoral experience, and especially

${ }^{12}$ Descriptive statistics are presented in Appendix A. 
those with both electoral and primary experience working in politics, had higher odds of establishing their career at the federal level compared to those without such experience. There are two possible contextual explanations for these unexpected findings. First, in 2015 there was a relatively high number of candidates with previous federal experience standing for the Liberals (15 out of 22). After suffering historic losses in 2011 and winning the fewest seats in the party's history, some of the Liberal MPs who lost their seats may not have immediately established themselves in new careers. With the Liberal Party apparently regaining momentum by 2015 , these individuals may have calculated that it was worth trying to re-enter Parliament. Second, on the Conservative side, the large number of voluntary exits and a relative lack of enthusiasm in a party that had been in government for nearly a decade, may have caused difficulties in candidate recruitment - even in winnable seats. Of the seven successful candidates who entered Parliament in 2015 with both electoral and primary political experience, five were Conservatives. Their clear political ambition - reflected both by working in politics and holding elected office - may have made these individuals more willing than others to stand for the Conservatives in the context of 2015.

However, these two explanations do not account for the large number of successful candidates with municipal experience. In an additional stage of analysis, it is confirmed that municipal experience, as distinct from federal or provincial experience, had a significant effect on winning in 2015, but not in $2011 .^{13}$ This finding will be

\footnotetext{
13 The magnitude of the increase in odds of winning (approximately twofold) is similar to that of electoral experience of any kind. Federal experience is significantly associated with a threefold increase in the odds of success, but provincial experience has no significant effect of its own. This additional analysis is available on request.
} 
discussed in the next section, but the lack of consistency in the effect of municipal electoral experience across the two elections leaves its inherent value questionable.

A further test of the first hypothesis investigates the role of prior political experience in establishing career progression within the House of Commons itself. Among MPs who have held office when their party was in government, no kind of preparliamentary political experience is significantly associated with higher odds of promotion to cabinet, controlling for other likely predictors. Similarly, MPs entering parliament at a younger age and MPs representing a riding in a demographically smaller province are not statistically advantaged. This latter finding is particularly important in its own right as it challenges the notion that MPs from less populous provinces are given disproportionate priority in cabinet appointments. Therefore, an MP representing one of the four ridings in Prince Edward Island or the sole riding in Yukon has no inherent advantage in career advancement.

\section{$<$ Table 3 here $>$}

Geographical considerations in cabinet appointments are, of course, more complex in reality. The Liberals held all four of Prince Edward Island's seats when the Conservatives formed a government in 2006, while Yukon's only electoral district was held by the NDP between 1993 and 2000, a party that has, to date, never entered federal government. The models in Table 3, however, control for such circumstances by accounting for the percentage of seats held by an MP's (governing) party at the earliest opportunity that he or she is eligible for promotion to cabinet. Table 3 shows that where 
the governing party holds a higher percentage of the seats in an MP's province, his or her odds of promotion to cabinet are marginally reduced. This marginal reduction in the odds of promotion, combined with the lack of significance of provincial size, provides only weak evidence of a geographically based 'representative imperative' in contemporary cabinet appointments. ${ }^{14}$

Promotion to cabinet, of course, is not the only possible avenue of promotion. For example, parliamentary secretaries are appointed to assist cabinet ministers. When the regression analysis in Table 3 is replicated with the dependent variable recoded to include parliamentary secretaries, the possession of any kind of political experience remains an insignificant predictor of parliamentary promotion. ${ }^{15}$ For an ambitious MP ultimately seeking a role in cabinet, or even at a lower level of government, there is little incentive to first acquire prior professional experience as a demonstration of political talent.

\subsection{The Challenge of Maintaining a Political Career}

\section{$<$ Table 4 here >}

The stability of an MP's position in parliament is not predicted by the possession of prior political experience. Indeed, on the face of it Table 4 would suggest that having primary experience in politics is associated with higher odds of involuntary exit, but the

\footnotetext{
${ }^{14}$ For additional robustness, the models in Table 3 were also run with provincial dummy variables (not reported; results are available on request). Out of the ten provinces and three territories, it was only serving a riding in Newfoundland and Labrador that was significantly associated with an MP having higher odds of cabinet promotion. All other odds ratios for the provincial dummy variables were statistically insignificant.

${ }^{15}$ Results of these additional analyses are available on request.
} 
relationship is statistically insignificant. Instead, lower odds of electoral defeat are significantly associated with being elected at a younger age and having a larger initial winning margin. More dramatically, serving in a cabinet role is associated with much lower odds of involuntary exit, even though serving in a governing party has no significant effect of its own. All else equal, the odds of an MP from a governing party exiting parliament involuntarily are, thus, indistinguishable from those of an opposition MP doing so. Federal politics in Canada is a team sport that can be both cruel and kind, especially for those without the apparent extra degree of protection offered by ministerial experience.

More than half of the former MPs who served between the $35^{\text {th }}$ and $41^{\text {st }}$ Parliaments were electorally defeated or deselected by their party. ${ }^{16}$ If this exit pattern continues, there is, thus, a higher probability of leaving parliament involuntarily than at a time of one's own choosing. Given these unfavourable odds against maintaining a federal political career, together with the lack of any statistically significant advantage associated with prior professional experience in politics, it is unsurprising that many aspiring MPs would seek to first establish themselves in a more stable career. Even among the most politically ambitious of individuals, the inherent risks associated with maintaining a career in the House of Commons would make it reasonable to initially pursue a different (non-political) line of work. In the event of involuntary exit, this prior work experience outside of politics may broaden their post-parliamentary 'fallback' career options.

\footnotetext{
${ }^{16} 52.9 \%$ were defeated electorally, a further 3.0 percent were deselected, and $42.7 \%$ retired or resigned voluntarily. The remaining $1.4 \%$ of former MPs died in office.
} 


\subsection{The Challenge of Premature Disengagement from Federal Politics}

The final hypothesis is that professional politicians are unlikely to dominate in the Canadian political system due to the normative tendency of MPs to see their federal career as interstitial, and thus to disengage prematurely from federal office. Thus, we are not just interested in the extent of voluntary turnover per se, but rather the timing of exit among those who have the fortune of choosing their time of withdrawal. We already know that just under half of parliamentary departures are voluntary; of these cases the mean tenure is 11.2 years, four years longer than the mean tenure of MPs who departed involuntarily. ${ }^{17}$ The difference is unsurprising. What is perhaps more surprising is that, compared to other pre-parliamentary occupational backgrounds, Table 5 shows that a professional background in politics (of any kind) does not significantly predict serving for a longer period in office. Instead, what is significant is an MP's age at which they enter parliament and whether or not he or she was a member of a governing party.

\section{$<$ Table 5 here $>$}

There are at least two probable explanations as to why professional politicians are statistically indistinguishable from others in the length of time they choose to spend in parliament. The first is that there are only a small number of those with primary professional experience who were able to choose when to withdraw from their federal career: only 13 in total left voluntarily, amounting to six tenths of the number who were

\footnotetext{
${ }^{17}$ The mean tenure of all former MPs overall is 8.7 years.
} 
defeated. This is an extension of the previous finding that professional experience in politics is not significantly associated with withstanding involuntary exit.

The second is that professional politicians who were able to choose when they retired from their federal careers may not have conceptualised a federal political career much differently from those from other professional backgrounds. In particular for those who had already calculated future advancement to be unlikely, those still interested in working may have been more attracted to the pursuit of a political career outside of parliament, conducted on their own terms. In this sense, they would reflect the general perception that federal parliamentary service is not necessarily the final stage of an individual's overall career. For MPs from non-political professional backgrounds, they may return to their former career once outside parliament. For those with preparliamentary experience in politics, federal office can indeed be seen as just one form of potential political involvement, not the zenith. Professional politicians may feel able to disengage prematurely from federal politics precisely because they understand that there are other avenues to continuing their work in the political field.

\section{Discussion}

For those concerned about legislatures dominated by professional politicians with little or no occupational experience of the world beyond politics, the Canadian House of Commons should offer some reassurance. Extending Docherty's (1997) argument on MPs' limited tenure, this study finds that MPs with a professional background in the field of politics itself amount only to a minority overall, at least among those serving since 1993. At the same time, however, for those concerned about a Canadian Parliament 
dominated by political amateurs, there may be some surprise at their lower level of dominance than may have been expected. For example, fewer than one in ten MPs worked primarily in politics itself before getting elected, but more than three times as many who worked in non-political occupations still possessed prior experience from holding elected office. Acknowledging distinct types of political experience - primary, secondary, and electoral - produces a more nuanced picture in the relative extent of political amateurism versus professionalism. Crucially, however, no kind of professional experience in politics is associated with any decisive advantage at each of the three stages of parliamentary career development. In other words, if an individual decides that he or she wants to become an MP, there is little evidence that political experience would be any real asset.

Establishing a career in federal politics, from getting nominated to getting promoted, depends not on pre-parliamentary political experience but on idiosyncratic and contextual factors. Candidates may exert the most control over their initial nomination, but this typically involves the ability to sign up more party members than the nearest challenger. To the extent that they are influential, riding associations do not tend to give much specific weight to prior political experience. Among those successfully nominated, the analysis presented in this paper shows that standing for the winning party is a far more powerful explanation of a candidate's success than any individual-level predictor.

However, the importance of the immediate electoral context raises a key question for further research. When comparing the candidates who successfully established their parliamentary careers in the 2011 federal election to those against their nearest challengers, the analysis found professional politicians no more likely to win than 
individuals without political experience - including electoral experience. This echoes previous research that finds no obvious integrated career ladder for politicians to make a smooth transition across the municipal, provincial and federal levels (Carty and Cross, 2010). The same cannot be said in 2015, when electoral experience was a significant predictor of a candidate's success. This leaves one of two conclusions: either this relationship was a one-off exception, or else it signals the emergence of a more obvious career ladder between different levels of government. In any case, close attention must be paid to the extent of integration in party organisation, particularly in the candidate selection process.

Koop (2011) suggests that the Liberal Party, for example, is much more integrated than Katz (2001) gives credit. Did the party make a strategic decision to actively recruit candidates with prior electoral experience, or was it simply a coincidence that many former municipal councillors stood for it in 2015? Were candidates with prior electoral experience more likely to make it through the party's vetting procedures over others, or were these types of candidate disproportionately likely to put themselves forward for consideration because of the political mood of 2015? It is difficult to assess the relative weight of structural-organisational factors over contextual explanations. For example, ahead of the election, the Liberals emphasised the 'open' nature of the party's nominations process, apparently giving local riding associations greater control over candidate selection. This may have encouraged candidates with a background in municipal politics to put themselves forward. However, the acclamation of a number of candidates by the central party structure appeared to undermine its commitment to decentralised 'open' nominations' (see Silcoff, 2014). There is, therefore, an apparent 
tension between efforts at decentralisation and centralisation, and between whether the Liberal Party develops into a more integrated organisation or develops into a looser 'movement' (as envisaged by its leader, Justin Trudeau). Either way, the future direction of party organisation - across all of Canada's political parties - is likely to influence the incentives on offer to prospective candidates, and the profile of candidates who are ultimately recruited.

Within parliament, professional politicians do not appear to have any edge over their peers in reaching cabinet. This is consistent with the idiosyncratic factors that conventionally determine cabinet appointments (Franks, 1987; Docherty, 1997; White, 2005). What is noteworthy, however, is the lack of convincing quantitative evidence that a geographical 'representative imperative' determines cabinet promotions. By the time Justin Trudeau abolished the formal positions of 'regional ministers' in 2015, it is possible that the perceived need to appoint cabinet ministers on the basis of geography had already weakened. This may give prime ministers the perception of greater flexibility, but there is not necessarily an accompanying trend to prioritise political experience as an increasingly important 'imperative' behind cabinet appointments.

Maintaining a career as an MP is essentially a touch-and-go endeavour. Among the MPs studied, there was a higher number that left involuntarily than voluntarily. The challenge of 'keeping the rascals in' is, therefore, a real one (Kerby and Blidook, 2008). Results from the 2015 federal election confirm this trend. Of the 338 members elected to the $42^{\text {nd }}$ Parliament, the majority of successful candidates were elected to Ottawa for the first time. Turnover is an inevitable consequence of any change of government, but the sheer magnitude of turnover remains a distinct feature of the Canadian political system. 
The absence of any apparent incumbency advantage no doubt challenges the ability of a professional politician to develop a stable political career, since the possession of preparliamentary political experience does not offset the odds of electoral defeat or deselection.

Disengaging from the House of Commons, relatedly, does not necessarily indicate the fulfilment of one's career in Canadian politics. In terms of voluntary turnover, longer tenure is not predicted by pre-parliamentary political experience. Among the two explanations offered for the lack of discernible difference in the timing of voluntary exit between professional politicians and other types of MP, one strong possibility is that professional politicians themselves are influenced by the general tendency of Canadian MPs to regard their time in parliament as interstitial (Franks, 1987). To test this hypothesis further, it would be advantageous to investigate not only MPs' preparliamentary occupational experience, but also their post-parliamentary employment patterns. Such data would be harder to obtain, but Samara Canada (2010) has already conducted an extensive series of qualitative exit interviews with former MPs. As well as probing them for their reflections on their parliamentary careers, it would be useful for future interview schedules to incorporate the issue of career development beyond parliament.

The findings from this paper, therefore, are far from the last word on the subject of professionalism versus amateurism in the Canadian House of Commons. Career patterns in any field are not constant, but are influenced by changing conditions and relative incentives. Indeed, developing a career in many fields has arguably become more competitive and less secure over time which, in turn, influences the types of careers 
people pursue in the first place (Biemann et al. 2011). If careers are to be understood as dynamic, not simply static, then changes in the development of political careers in Canada should be seen accordingly.

In conclusion, as the relative extent of political professionalism versus political amateurism continues to provoke interest, this paper makes an important contribution to the literature in three main respects. First, in descriptive terms, it confirms that political amateurs do indeed outnumber professional politicians - of all forms - in the Canadian House of Commons. Second, it shows that career development theory provides a valuable framework for the systematic analysis of political careers. Finally, by analysing data on the careers of over one thousand politicians over the course of two decades, it provides a clear explanation for the relative dominance of amateurs over professionals among Canadian MPs. At the key stages of establishing, maintaining, and withdrawing from their parliamentary careers, the possession of prior political experience is unrelated to any decisive or consistent advantage in overcoming the challenging features of the Canadian political system. This leaves little incentive for individuals to work in the field of politics itself before standing for federal office. 
Table 1: An adaptation of Super's (1957) typology of career stages, with corresponding hypotheses

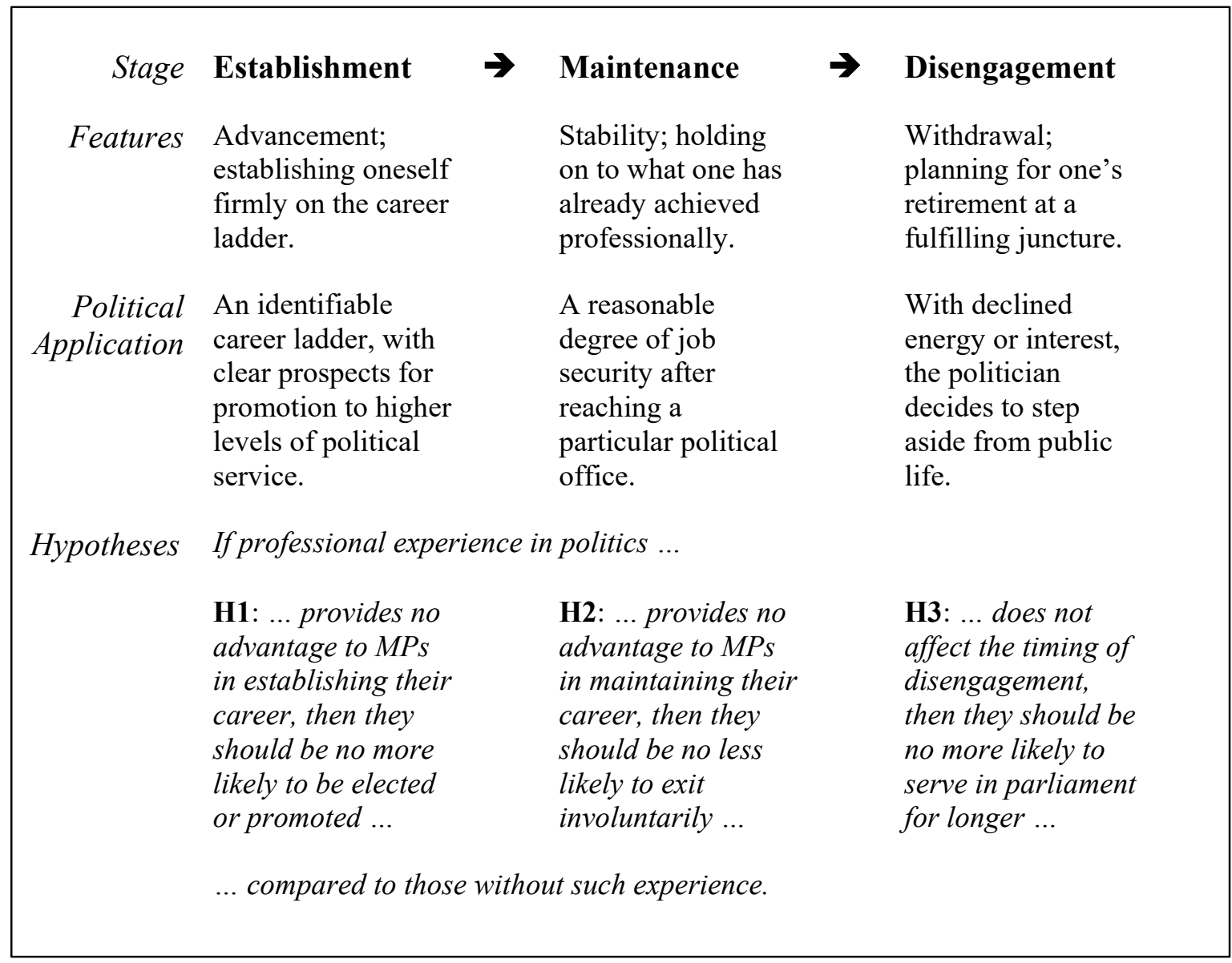


Table 2: Predictors of successfully establishing a parliamentary career (over finishing second) in 2011 and 2015

\begin{tabular}{|c|c|c|c|c|c|c|c|c|c|}
\hline & 1 & 2 & 3 & 4 & 5 & 6 & 7 & 8 & 9 \\
\hline & \multicolumn{4}{|c|}{ Winning a Seat in 2011} & \multicolumn{5}{|c|}{ Winning a Seat in 2015} \\
\hline \multicolumn{10}{|l|}{ Political Experience } \\
\hline Primary & $\begin{array}{c}0.293 \\
(0.170)^{* *}\end{array}$ & - & - & - & $\begin{array}{c}1.505 \\
(0.669)\end{array}$ & - & - & - & - \\
\hline Secondary & - & $\begin{array}{c}0.814 \\
(0.457)\end{array}$ & - & - & - & $\begin{array}{c}0.905 \\
(0.361)\end{array}$ & - & - & - \\
\hline Electoral & - & - & $\begin{array}{c}0.619 \\
(0.250)\end{array}$ & - & - & - & $\begin{array}{c}2.038 \\
(\mathbf{0 . 6 8 8})^{* *}\end{array}$ & - & - \\
\hline Primary + Electoral & - & - & - & $\begin{array}{c}0.599 \\
(0.739)\end{array}$ & - & - & - & $\begin{array}{c}8.822 \\
(7.458) * *\end{array}$ & - \\
\hline Secondary + Electoral & - & - & - & - & - & - & - & - & $\begin{array}{c}3.294 \\
(2.670)\end{array}$ \\
\hline Age (at Election) & $\begin{array}{c}0.926 \\
(0.013)^{* * * *}\end{array}$ & $\begin{array}{c}0.932 \\
(0.013)^{* * * *}\end{array}$ & $\begin{array}{c}0.935 \\
(0.013)^{* * *}\end{array}$ & $\begin{array}{c}0.932 \\
(0.013)^{* * * *}\end{array}$ & $\begin{array}{c}0.978 \\
(0.012) *\end{array}$ & $\begin{array}{c}0.975 \\
(0.012)^{* *}\end{array}$ & $\begin{array}{c}0.969 \\
(0.012)^{* *}\end{array}$ & $\begin{array}{c}0.974 \\
(0.012)^{* *}\end{array}$ & $\begin{array}{c}0.974 \\
(0.012)^{* *}\end{array}$ \\
\hline Local (to Riding) & $\begin{array}{c}0.655 \\
(0.205)\end{array}$ & $\begin{array}{c}0.680 \\
(0.210)\end{array}$ & $\begin{array}{c}0.696 \\
(0.216)\end{array}$ & $\begin{array}{c}0.694 \\
(0.215)\end{array}$ & $\begin{array}{c}1.077 \\
(0.291)\end{array}$ & $\begin{array}{c}1.081 \\
(0.291)\end{array}$ & $\begin{array}{c}1.039 \\
(0.282)\end{array}$ & $\begin{array}{c}1.077 \\
(0.294)\end{array}$ & $\begin{array}{c}1.063 \\
(0.288)\end{array}$ \\
\hline Winning Party & $\begin{array}{c}5.383 \\
(2.143)^{* * * *}\end{array}$ & $\begin{array}{c}4.808 \\
(1.866)^{* * *}\end{array}$ & $\begin{array}{c}4.655 \\
(1.815)^{* * *}\end{array}$ & $\begin{array}{c}4.829 \\
(1.877)^{* * *}\end{array}$ & $\begin{array}{c}21.026 \\
(6.084)^{* * * *}\end{array}$ & $\begin{array}{c}20.493 \\
(5.891)^{* * *}\end{array}$ & $\begin{array}{c}20.203 \\
(5.833) * * *\end{array}$ & $\begin{array}{c}22.275 \\
(6.476) * * *\end{array}$ & $\begin{array}{c}20.488 \\
(5.910)^{* * * *}\end{array}$ \\
\hline Seat Change & $\begin{array}{c}2.087 \\
(0.979)\end{array}$ & $\begin{array}{c}1.981 \\
(11.702)\end{array}$ & $\begin{array}{c}1.935 \\
(0.912)\end{array}$ & $\begin{array}{c}1.988 \\
(0.940)\end{array}$ & $\begin{array}{c}0.561 \\
(0.185)^{*}\end{array}$ & $\begin{array}{c}0.558 \\
(0.184) *\end{array}$ & $\begin{array}{c}0.584 \\
(0.194)\end{array}$ & $\begin{array}{c}0.610 \\
(0.206)\end{array}$ & $\begin{array}{c}0.548 \\
(0.181)^{*}\end{array}$ \\
\hline
\end{tabular}


Continued

\begin{tabular}{|c|c|c|c|c|c|c|c|c|c|}
\hline Constant & $\begin{array}{c}20.769 \\
(17.369) * * *\end{array}$ & $\begin{array}{c}14.558 \\
(11.702)^{* * *}\end{array}$ & $\begin{array}{c}13.589 \\
(10.845) * * *\end{array}$ & $\begin{array}{c}14.359 \\
(11.496)^{* * * *}\end{array}$ & $\begin{array}{c}1.472 \\
(1.022)\end{array}$ & $\begin{array}{c}1.815 \\
(1.218)\end{array}$ & $\begin{array}{c}2.140 \\
(1.446)\end{array}$ & $\begin{array}{c}1.598 \\
(1.080)\end{array}$ & $\begin{array}{c}1.883 \\
(1.255)\end{array}$ \\
\hline$N$ & 217 & 217 & 217 & 217 & 375 & 375 & 375 & 375 & 375 \\
\hline Log Likelihood & -124.37 & -126.58 & -125.93 & -126.56 & -178.89 & -179.28 & -177.06 & -175.30 & -178.16 \\
\hline Pseudo $R^{2}$ & 0.17 & 0.16 & 0.16 & 0.16 & 0.31 & 0.31 & 0.32 & 0.32 & 0.31 \\
\hline$\chi^{2}$ (d.f.) & $52.08(5)$ & $47.67(5)$ & $48.97(5)$ & $47.71(5)$ & $159.52(5)$ & $158.74(5)$ & $163.18(5)$ & $167.69(5)$ & $160.97(5)$ \\
\hline
\end{tabular}

Entries are odds ratios from logistic regressions; standard errors are reported in parentheses.

The dependent variable in each model is a binary outcome, coded ' 1 ' if candidate wins a seat in Parliament, or ' 0 ' if the candidate came second. Only ridings where a new MP was elected are included in the sample. Only one candidate had 'Secondary + Electoral' experience in 2011; consequently, this variable was dropped from the analysis.

${ }^{*} p<.10 ; * * p<.05 ; * * * p<.01$ 
Table 3: Predictors of cabinet experience among former MPs from a governing party

\begin{tabular}{|c|c|c|c|c|}
\hline & 1 & 2 & 3 & 4 \\
\hline & \multicolumn{4}{|c|}{ Cabinet Experience } \\
\hline \multicolumn{5}{|l|}{ Political Experience } \\
\hline Primary & $\begin{array}{c}0.849 \\
(0.437)\end{array}$ & - & - & - \\
\hline Secondary & - & $\begin{array}{c}1.104 \\
(0.376)\end{array}$ & - & - \\
\hline Electoral & - & - & $\begin{array}{c}1.137 \\
(0.274)\end{array}$ & - \\
\hline Primary + Electoral & - & - & - & $\begin{array}{c}2.089 \\
(1.308)\end{array}$ \\
\hline Age (at Entry) & $\begin{array}{c}0.987 \\
(0.013)\end{array}$ & $\begin{array}{c}0.987 \\
(0.013)\end{array}$ & $\begin{array}{c}0.986 \\
(0.013)\end{array}$ & $\begin{array}{l}0.988 \\
(0.013)\end{array}$ \\
\hline Province Size & $\begin{array}{c}0.997 \\
(0.008)\end{array}$ & $\begin{array}{c}0.997 \\
(0.008)\end{array}$ & $\begin{array}{c}0.997 \\
(0.008)\end{array}$ & $\begin{array}{c}0.997 \\
(0.008)\end{array}$ \\
\hline Provincial Party Strength & $\begin{array}{c}0.989 \\
(0.004)^{* * *}\end{array}$ & $\begin{array}{c}0.989 \\
(0.004)^{* *}\end{array}$ & $\begin{array}{c}0.989 \\
(\mathbf{0 . 0 0 4})^{* * *}\end{array}$ & $\begin{array}{c}0.987 \\
(0.004)^{* * *}\end{array}$ \\
\hline Tenure & $\begin{array}{c}1.082 \\
(0.023)^{* *}\end{array}$ & $\begin{array}{c}1.081 \\
(0.023)^{* *}\end{array}$ & $\begin{array}{c}1.082 \\
(0.023)^{* *}\end{array}$ & $\begin{array}{c}1.085 \\
(0.023)^{* *}\end{array}$ \\
\hline Margin & $\begin{array}{c}1.022 \\
(0.008)^{* * *}\end{array}$ & $\begin{array}{c}1.022 \\
(0.008)^{* *}\end{array}$ & $\begin{array}{c}1.022 \\
(0.008)^{* *}\end{array}$ & $\begin{array}{c}1.021 \\
(0.008)^{*}\end{array}$ \\
\hline Constant & $\begin{array}{c}0.719 \\
(0.568)\end{array}$ & $\begin{array}{c}0.681 \\
(0.525)\end{array}$ & $\begin{array}{c}0.687 \\
(0.531)\end{array}$ & $\begin{array}{c}0.640 \\
(0.496)\end{array}$ \\
\hline$N$ & 398 & 398 & 398 & 398 \\
\hline Log Likelihood & -237.62 & -237.62 & -237.52 & -236.99 \\
\hline Pseudo $R^{2}$ & 0.07 & 0.07 & 0.07 & 0.07 \\
\hline$\chi^{2}$ (d.f.) & $35.93(6)$ & $35.91(6)$ & $36.11(6)$ & $37.18(6)$ \\
\hline
\end{tabular}

Entries are odds ratios from logistic regressions; standard errors are reported in parentheses.

The dependent variable in each model is cabinet experience, coded ' 1 ' if an MP has served in cabinet and ' 0 ' otherwise. The data are restricted only to former MPs who have served when their party has been in government. Incumbent MPs and those only with experience in opposition are excluded. None of these individuals possessed 'Secondary + Electoral' political experience, hence its omission as an independent variable.

${ }^{*} p<.10 ; * * p<.05 ; * * * p<.01$ 
Table 4: Predictors of involuntary exit from parliament among former MPS

\begin{tabular}{|c|c|c|c|c|}
\hline & 1 & 2 & 3 & 4 \\
\hline & \multicolumn{4}{|c|}{ Involuntary Exit } \\
\hline \multicolumn{5}{|l|}{ Political Experience } \\
\hline Primary & $\begin{array}{c}1.123 \\
(0.415)\end{array}$ & - & - & - \\
\hline Secondary & - & $\begin{array}{c}0.976 \\
(0.274)\end{array}$ & - & - \\
\hline Electoral & - & - & $\begin{array}{c}0.884 \\
(0.159)\end{array}$ & - \\
\hline Primary + Electoral & - & - & - & $\begin{array}{c}1.113 \\
(0.838)\end{array}$ \\
\hline Age (at Entry) & $\begin{array}{c}0.984 \\
(\mathbf{0 . 0 0 8})^{*}\end{array}$ & $\begin{array}{c}0.983 \\
(0.008) *\end{array}$ & $\begin{array}{c}0.984 \\
(\mathbf{0 . 0 0 8})^{*}\end{array}$ & $\begin{array}{c}0.983 \\
(0.008)^{*}\end{array}$ \\
\hline Margin & $\begin{array}{c}0.969 \\
(0.006)^{* * *}\end{array}$ & $\begin{array}{c}0.969 \\
(0.006)^{* * *}\end{array}$ & $\begin{array}{c}0.969 \\
(0.006)^{* *}\end{array}$ & $\begin{array}{c}0.969 \\
(0.006)^{* *}\end{array}$ \\
\hline Cabinet & $\begin{array}{c}0.555 \\
(0.123)^{* * *}\end{array}$ & $\begin{array}{c}0.555 \\
(0.123)^{* * *}\end{array}$ & $\begin{array}{c}0.555 \\
(0.123)^{* * *}\end{array}$ & $\begin{array}{c}0.554 \\
(0.123)^{* *}\end{array}$ \\
\hline Government & $\begin{array}{c}0.886 \\
(0.157)\end{array}$ & $\begin{array}{c}0.887 \\
(0.157)\end{array}$ & $\begin{array}{c}0.897 \\
(0.159)\end{array}$ & $\begin{array}{c}0.885 \\
(0.157)\end{array}$ \\
\hline Constant & $\begin{array}{c}5.482 \\
(2.353)^{* *}\end{array}$ & $\begin{array}{c}5.666 \\
(2.368)^{* * *}\end{array}$ & $\begin{array}{c}5.508 \\
(2.312)^{* * *}\end{array}$ & $\begin{array}{c}5.650 \\
(2.361)^{* * *}\end{array}$ \\
\hline$N$ & 700 & 700 & 700 & 700 \\
\hline Log Likelihood & -457.38 & -457.43 & -457.20 & -457.41 \\
\hline Pseudo $R^{2}$ & 0.05 & 0.05 & 0.05 & 0.05 \\
\hline$\chi^{2}$ (d.f.) & $46.02(5)$ & $45.93(5)$ & $46.39(5)$ & $46.96(5)$ \\
\hline
\end{tabular}

Entries are odds ratios from logistic regressions; standard errors are reported in parentheses.

The dependent variable in each model is involuntary exit, coded ' 1 ' if a former MP exited parliament through electoral defeat or deselection, or ' 0 ' if the MP retired, resigned, or died in office. Cases are restricted to former MPs; none of these individuals possessed 'Secondary + Electoral' political experience, hence its omission.

$* p<.10 ; * * p<.05 ; * * * p<.01$ 
Table 5: Predictors of tenure among MPs exiting parliament voluntarily

$1+2$

3

4

Tenure

Political Experience

$\begin{array}{cc}0.118 \\ \text { Primary } & (1.516)\end{array}$

Secondary

0.136

(1.057)

Electoral

$(0.677)$

Primary + Electoral

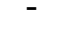

\begin{tabular}{|c|c|c|c|c|}
\hline Age (at Entry) & $\begin{array}{c}-0.242 \\
(0.031)^{* *}\end{array}$ & $\begin{array}{c}-0.242 \\
(0.030)^{* * *}\end{array}$ & $\begin{array}{c}-0.236 \\
(0.031)^{* *}\end{array}$ & $\begin{array}{c}-0.242 \\
(0.030) * *\end{array}$ \\
\hline Margin & $\begin{array}{c}0.008 \\
(0.019)\end{array}$ & $\begin{array}{c}0.008 \\
(0.019)\end{array}$ & $\begin{array}{c}0.008 \\
(0.019)\end{array}$ & $\begin{array}{c}0.008 \\
(0.019)\end{array}$ \\
\hline Cabinet & $\begin{array}{c}0.812 \\
(0.806)\end{array}$ & $\begin{array}{c}0.809 \\
(0.806)\end{array}$ & $\begin{array}{c}0.781 \\
(0.805)\end{array}$ & $\begin{array}{c}0.817 \\
(0.806)\end{array}$ \\
\hline Government & $\begin{array}{c}3.555 \\
(0.710)^{* *}\end{array}$ & $\begin{array}{c}3.541 \\
(0.713)^{* * *}\end{array}$ & $\begin{array}{c}3.630 \\
(0.713)^{* *}\end{array}$ & $\begin{array}{c}3.551 \\
(0.709)^{* *}\end{array}$ \\
\hline Constant & $\begin{array}{c}20.353 \\
(1.643)^{* *}\end{array}$ & $\begin{array}{c}20.383 \\
(1.608)^{* * *}\end{array}$ & $\begin{array}{c}20.261 \\
(1.610)^{* *}\end{array}$ & $\begin{array}{c}20.375 \\
(1.608)^{* * *}\end{array}$ \\
\hline$N$ & 299 & 299 & 299 & 299 \\
\hline Adjusted $R^{2}$ & 0.28 & 0.28 & 0.28 & 0.28 \\
\hline
\end{tabular}

Entries are ordinary least squares (OLS) regression coefficients; standard errors are reported in parentheses.

The dependent variable in each model is an MP's length of time in office, in years. Cases are restricted to former MPs who exited parliament voluntarily (through resignation or retirement); none of these individuals possessed 'Secondary + Electoral' political experience, hence its omission.

${ }^{*} p<.10 ; * * p<.05 ; * * * p<.01$ 


\section{References}

Arthur, M. (2008) 'Examining Contemporary Careers: A Call for Interdisciplinary Inquiry’, Human Relations, 61 (2), 163-186.

Aryee, S., Wah Chay, Y. and Chew, J. (1994) 'An Investigation of the Predictors and Outcomes of Career Commitment in Three Career Stages', Journal of Vocational Behavior, 44 (1), 1-16.

Atkinson, M. and Docherty, D. (1992) 'Moving Right Along: The Roots of Amateurism in the Canadian House of Commons', Canadian Journal of Political Science, 25 (2), 295-318.

Bakvis, H. (1989) 'Regional Ministers, National Policies and the Administrative State in Canada: The Regional Dimension in Cabinet Decision-Making, 1980-1984', Canadian Journal of Political Science, 21 (3), 539-567.

Barrie, D. and Gibbins, R. (1989) 'Parliamentary Careers in the Canadian Federal State', Canadian Journal of Political Science, 22 (1), 137-145.

Biemann, T., Fasang, A. E. and Grunow, D. (2011) 'Do Economic Globalization and Industry Growth Destabilize Careers? An Analysis of Career Complexity and Career Patterns Over Time', Organization Studies, 32 (12), 1639-1663.

Bittner, A. and Koop, R. (2013) Parties, Elections, and the Future of Canadian Politics, Vancouver, UBC Press.

Cairney, P. (2007) 'The Professionalisation of MPs: Refining the 'Politics-Facilitating' Explanation', Parliamentary Affairs, 60 (2), 212-233. 
Carty, R. K. and Cross, W. (2010) 'Political Parties and the Practice of Brokerage Politics'. In: D. E. Smith and J. Courtney (eds.) Oxford Handbook of Canadian Politics, Oxford, Oxford University Press, 191-207.

Carty, R. K. and Eagles, M. (2005) Politics is Local: National Politics at the Grassroots, Toronto, Oxford University Press.

Casstevens, T. and Denham, III, W. (1970) 'Turnover and Tenure in the Canadian House of Commons, 1867-1968', Canadian Journal of Political Science, 3 (4), 655-661.

Cowley, P. (2012) 'Arise, Novice Leader! The Continuing Rise of the Career Politician in Britain', Politics, 31 (1), 31-38.

Criddle, B. (2010) 'More Diverse, Yet More Uniform: MPs and Candidates'. In: D. Kavanagh \& P. Cowley (eds.) The British General Election of 2010, Basingstoke, Palgrave Macmillan, 306-329.

Docherty, D. (1997) Mr. Smith Goes to Ottawa: Life in the House of Commons, Vancouver, UBC Press.

Docherty, D. (2011) 'The Canadian Political Career Structure: From Stability to Free Agency', Regional and Federal Studies, 21 (2), 185-203.

Erickson, L. (1997) 'Canada'. In: P. Norris (ed.) Passages to Power: Legislative Recruitment in Advanced Democracies, Cambridge, Cambridge University Press, 3355.

Franks, C. E. S. (1987) The Parliament of Canada, Toronto, University of Toronto Press. Hepburn, B. (2015) 'How Justin Trudeau Picked his New Cabinet', Toronto Star, 1 November, accessed 
at https://www.thestar.com/opinion/commentary/2015/11/01/how-justin-trudeaupicked-his-new-cabinet-hepburn.html on 3 January 2018.

Hess, N. and Jepsen, D. (2009) 'Career Stage and Generational Differences in Psychological Contracts', Career Development International, 14 (3), 261-283.

Kam, C. (2006) 'Demotion and Dissent in the Canadian Liberal Party', British Journal of Political Science, 36 (3), 561-574.

Katz, R. (2001) 'The Problem of Candidate Selection and Models of Party Democracy', Party Politics, 7 (3), 277-296.

Kerby, M. (2009) 'Worth the Wait: Determinants of Ministerial Appointment in Canada, 1935-2008', Canadian Journal of Political Science, 42 (3), 593-611.

Kerby, M. and Blidook, K. (2008) '... if I stay it will be double ... Determinants of Voluntary Legislative Turnover in Canada: 1945-2006'. Presented at The European Consortium for Political Research Joint Session. Rennes, France, 11-16 April 2008.

Kerby, M. and Blidook, K. (2011) 'It's Not You, It's Me: Determinants of Voluntary Legislative Turnover in Canada', Legislative Studies Quarterly, 36 (4), 621-643.

King, A. (1981) 'The Rise of the Career Politician in Britain - And Its Consequences', British Journal of Political Science, 11 (3), 249-285.

Koop, R. (2011) Grassroots Liberals: Organizing for Local and National Politics, Vancouver, UBC Press.

Library of Parliament (2016) 'Members of the House of Commons', accessed at https://lop.parl.ca/sites/ParlInfo/default/en_CA on 3 January 2018.

Loat, A. (2011) 'Member of Parliament: A Job With No Job Description', Canadian Parliamentary Review, 34 (1), 23-29. 
Matland, R. and Studlar, D. (2004) 'Determinants of Legislative Turnover: A CrossNational Analysis', British Journal of Political Science, 34 (1), 87-108.

Matthews, D. (1984) 'Legislative Recruitment and Legislative Careers', Legislative Studies Quarterly, 9 (4), 547-585.

Mitchell, K., Levin, A. and Krumboltz, J. (1999) 'Planned Happenstance: Constructing Unexpected Career Opportunities', Journal of Counseling \& Development, 77 (2), $115-124$.

Pruysers, S. and Cross, W. (2016) 'Candidate Selection in Canada: Local Autonomy, Centralization, and Competing Democratic Norms', American Behavioral Scientist, 60 (7), 781-798.

Rahat, G. (2007) 'Candidate Selection: The Choice Before the Choice', Journal of Politics, 18 (1), 157-170.

Rohde, D. (1979) 'Risk-Bearing and Progressive Ambition: The Case of Members of the United States House of Representatives', American Journal of Political Science, 23 (1), 1-26.

Samara Canada (2010) 'The Accidental Citizen?' accessed at http://www.samaracanada.com/research/political-leadership/mp-exit-interviews/theaccidental-citizen-report on 10 December 2016.

Savoie, D. (1999) Governing from the Centre: The Concentration of Power in Canadian Politics, Toronto, University of Toronto Press.

Schlesinger, J. (1966) Ambition and Politics: Political Careers in the United States, Chicago, Rand McNally. 
Silcoff, S. (2014) 'Messy nomination battle could hinder Liberal prospects in Ottawa riding', The Globe and Mail, 8 December, available at http:/www.theglobeandmail.com/news/politics/messy-nomination-battle-couldhinder-liberal-prospects-in-ottawa-riding/article21987208/ on 10 December 2016. Super, D. (1957) The Psychology of Careers, New York, John Wiley. White, G. (2005) Cabinets and First Ministers in Canada, Vancouver, UBC Press. 


\section{Appendix}

Table A1: MPs with professional experience in politics (\%) serving between 1993 and 2015

\section{Parliament}

\begin{tabular}{lrrrrrrrr}
\hline & $\mathbf{3 5}^{\text {th }}$ & $\mathbf{3 6}^{\text {th }}$ & $\mathbf{3 7}^{\text {th }}$ & $\mathbf{3 8}^{\text {th }}$ & $\mathbf{3 9}^{\text {th }}$ & $\mathbf{4 0}^{\text {th }}$ & $\mathbf{4 1}^{\text {st }}$ & All \\
Political Experience & $1993-$ & $1997-$ & $2000-$ & $2004-$ & $2006-$ & $2008-$ & $2011-$ & $1993-$ \\
& 1997 & 2000 & 2004 & 2006 & 2008 & 2011 & 2015 & 2015 \\
\hline Primary & 4.6 & 5.1 & 5.1 & 8.1 & 7.3 & 7.6 & 5.6 & $\mathbf{5 . 0}$ \\
Secondary & 8.2 & 9.3 & 9.3 & 11.0 & 8.5 & 9.8 & 10.3 & $\mathbf{8 . 9}$ \\
Electoral & 26.6 & 29.3 & 32.3 & 32.0 & 31.2 & 28.3 & 21.8 & $\mathbf{2 7 . 8}$ \\
Electoral + Primary & 1.0 & 2.3 & 2.6 & 2.6 & 3.8 & 5.1 & 4.7 & $\mathbf{3 . 0}$ \\
Electoral + Secondary & 0.0 & 0.0 & 0.3 & 0.3 & 0.3 & 0.6 & 0.0 & $\mathbf{0 . 5}$ \\
None & 59.5 & 54.0 & 50.5 & 46.0 & 48.9 & 48.6 & 57.6 & $\mathbf{5 4 . 9}$ \\
\hline Total \% & 100.0 & 100.0 & 100.0 & 100.0 & 100.0 & 100.0 & 100.0 & 100.0 \\
$N$ & 304 & 311 & 313 & 309 & 317 & 315 & 321 & 836 \\
Missing & 0 & 0 & 0 & 0 & 0 & 0 & 2 & 2 \\
\hline
\end{tabular}

$N$ s do not equal the number of seats in a given parliament. They represent the total number of legislators who served in a given parliament (including those elected in by-elections). In the $41^{\text {st }}$ Parliament, two cases were excluded due to incomplete data. The full dataset is available on request.

Table A2: Candidates with professional experience in politics (\%) standing in the 2011 and 2015 federal elections

\section{1}

2015

\begin{tabular}{lrrrrr}
\cline { 3 - 6 } Political Experience & Winners & Runners $-U p$ & & Winners & Runners $-U p$ \\
\cline { 3 - 6 } \cline { 5 - 6 } Primary & 6.4 & 8.3 & & 9.9 & 8.7 \\
Secondary & 8.3 & 9.3 & & 11.8 & 12.8 \\
Electoral & 11.9 & 25.9 & & 26.6 & 17.4 \\
Electoral + Primary & 1.8 & 1.9 & & 3.4 & 1.2 \\
Electoral + Secondary & 0.0 & 0.9 & & 4.9 & 1.7 \\
None & 71.6 & 54.6 & & 43.3 & 58.2 \\
\hline Total \% & 100.0 & 100.0 & & 100.0 & 100.0 \\
$N$ & 109 & 108 & & 203 & 172 \\
Missing & 2 & 3 & & 11 & 42 \\
\hline
\end{tabular}

Winners are those who established their parliamentary careers in each respective election. Runners-up are those who finished second in the ridings won by a new MP. The full dataset is available on request. 